\title{
Situation of Pharmaceuticals in Albania 2014-2018
}

\author{
Ilda Mallkuçi ${ }^{1 *}$, Narvina Sinani ${ }^{1}$, and Ina Thereska ${ }^{2}$ \\ ${ }^{1}$ National Agency for Medicines and Medical devices, Tirana, Albania \\ ${ }^{2}$ Universiteti Mjekësor i Tiranës, Fakulteti i Stomatologjisë, Tirana, Albania
}

*Corresponding author: Ilda Mallkuçi, National Agency for Medicines and Medical devices, Tirana, Albania, E-mail: ildushka81@hotmail.com

Received: 24 Jun, 2020 | Accepted: 11 Jul, 2020 | Published: 18 Jul, 2020

Citation: Mallkuçi I, Sinani N, Thereska I (2020) Situation of Pharmaceuticals in Albania 2014-2018. J Drug Res Dev 6(2): dx.doi.org/10.16966/24701009.156

Copyright: (C) 2020 Mallkuçi I, et al. This is an open-access article distributed under the terms of the Creative Commons Attribution License, which permits unrestricted use, distribution, and reproduction in any medium, provided the original author and source are credited.

\begin{abstract}
Background: Globally and locally the pharmaceutical industry is highly regulated. In Albania the regulatory requirements are changing with different amendments of Low and Regulations to ensure the supply with high pharmaceutical quality, safety and efficacy of medicines. The accelerated procedure for medicines that come from EU/FDA, has given to the patients access to new medicines such as orphans and biosimilars in a very short time from their first marketing authorization. In this way the patient can achieve new pharmaceuticals which are safe, efficient and qualitative and the most important point innovative medicines that are authorized for marketing in USA and EU.

Methods \& Results: Statistical data points indicate that in Albania from 2014-2018 are authorized for marketing: EU Centralized procedure 267 medicines and FDA 13 medicines, from 1666 authorized for marketing in total. From the remaining medicines, 1386 of them are from EU countries or West Balkans region. The trend of new medicines that are submitting at the Albanian Agency, from different pharmaceutical companies has increased from 2014 to present day, with new biosimilars, orphans and new medicines for acromegaly or antineoplastic agents.

Conclusions: In Albania we have an urgent need for regulations that govern interchangeability/substitutability of biosimilars, extrapolation of their indications, and new legislation on orphans. The purpose is to find common elements in the most varied regulatory systems that enable companies to identify the documents and information required by international regulators and understand techniques that can help to reduce cost and time in the marketing authorization approval process globally. An analysis of the legislation of the different countries and an identification of the common elements must be discussed in a practical way.
\end{abstract}

Recommendations: Approaching the Albanian legislation with EU legislation regarding innovative medicines which can promote competition between different medicines for the same pathology reducing costs of therapy.

Keywords: Regulatory; Biosimilar; Marketing Authorization; Indication extrapolation; Interchangeability; FDA; EU; Antineoplastic agent

\section{Background}

Globally and locally the pharmaceutical industry is highly regulated. In Albania the regulatory requirements are changing with different amendments of Low and Regulations to ensure the supply with high pharmaceutical quality, safety and efficacy of medicines. The accelerated procedure for medicines that come from EU/FDA, has given to the patients access to new medicines such as orphans and biologicals and biosimilars in a very short time from their first marketing authorization. In this way the patient can achieve new pharmaceuticals which are safe, efficient and qualitative and the most important point innovative medicines that are authorized for marketing in USA and EU. There are also a large number of medicines that arrives from Turkey and Balkans. They are also in the same way (according to their marketing authorization files), safe, efficient and qualitative. The Albanian Low and Regulations must change mostly for the technical parts required for MA and Renewal in Albania.
In many cases the documentation needed for these procedure is exaggerated (the literature reference clinical and preclinical for generic drug products), and in many cases is very poor (for biological and biosimilar for example). For Orphan medicines there are not specific requirements, they are treated just like all the other medicines that apply for Marketing Authorization (MA) or Renewal [1,2].

In this situation we need regulatory changes in order to have registered more EU, USA, Japan etc drugs in the Republic of Albania.

\section{Methods \& Results}

Statistical data points taken from the National Register of Medicines, indicates that in Albania from 2014 - 2018 are authorized for marketing: EU Centralized procedure 267 medicines and FDA 13 medicines, from 1666 authorized for marketing in total. From the remaining medicines, 1386 of them are from EU countries or West Balkans region. The trend of new medicines that are submitting at 
the Albanian Agency, from different pharmaceutical companies has increased from 2014 to present day, with new biosimilars, orphans and new medicines for acromegaly or antineoplastic agents [3].

The below tables shows the total number of medicines authorized for marketing from the start and the renewed ones from 29.01.2014 until 12.12. 2018. They are categorized according to their referent country (the country that releases the Certificate of the Pharmaceutical Product).

\section{So the classification is: Medicines from Turkey, FDA and EMA.}

According to this classification, we can understand from the total number of medicines authorized and renewed in one year (for each table), how many of them were medicines that come from USA, EU and how many from Turkey. This is important for a country which is still in transition and provenience of medicines are not only EU countries and USA, but also Turkey, Balkans etc [3]

- MA medicines: in total for 4 years, 2014-2018: 1666

- Renewed medicines for 4 years, 2014-2018: 1927

- Medicines with Turkish MAH for 4 years 2014-2018: 467

- Medicines with EMA MAH for 4 years 2014-2018: 267

- Medicines with FDA MAH for 4 years 2014-20182014-2018: 13

As we can conclude the number of total medicines authorized for marketing in Albania is 1666 and the renewed one is 1927. This shows a large number of registrations and renewals in Albania, taking in account that Albania is a small country with barely 3 million of people. The trend shows that the number of medicines that come from Turkia (467) is bigger that the medicines that comes from EU (267 centralized procedure) and USA (13 centrilazide procedure). But in this tables are not shown the national procedures from EU countries, so if we take on account them, we can say that the number of medicines that came from EU countries and USA in total, are near the range with the ones that came from Turkey and we have also medicines that came from our neighbours (Balkans), which are always in a large number [3] (Table 1-5).

\section{Conclusions}

In Albania we have an urgent need for regulations that govern interchange ability/substitutability of biosimilars, extrapolation of their indications, and new legislation on orphans. The purpose is to find common elements in the most varied regulatory systems that enable companies to identify the documents and information required by international regulators and understands techniques that can help to reduce cost and time in the marketing authorization approval process globally. An analysis of the legislation of the different countries and an identification of the common elements must be discussed in a practical way. These changes will bring new innovative medicines from USA, EU, Japan etc.
Table 1: Medicines 2014.

\begin{tabular}{|c|c|c|c|c|}
\hline MA & Renewal & From Turkey & From FDA & From EMA \\
\hline 248 & 310 & 29 & 5 & 66 \\
\hline
\end{tabular}

Table 2: Medicines 2015.

\begin{tabular}{|c|c|c|c|c|}
\hline MA & Renewal & From Turkey & From FDA & From EMA \\
\hline 267 & 314 & 56 & 7 & 42 \\
\hline
\end{tabular}

Table 3: Medicines 2016.

\begin{tabular}{|c|c|c|c|c|}
\hline $\begin{array}{c}\text { Autorizim } \\
\text { Tregtimi }\end{array}$ & $\begin{array}{c}\text { Rinovim I Autorizimit } \\
\text { Per Tregtim }\end{array}$ & $\begin{array}{c}\text { From } \\
\text { Turkey }\end{array}$ & From FDA & $\begin{array}{c}\text { From } \\
\text { EMA }\end{array}$ \\
\hline 373 & 462 & 127 & 0 & 62 \\
\hline
\end{tabular}

Table 4: Medicines 2017.

\begin{tabular}{|c|c|c|c|c|}
\hline $\begin{array}{c}\text { Autorizim } \\
\text { Tregtimi }\end{array}$ & $\begin{array}{c}\text { Rinovim I Autorizimit } \\
\text { Per Tregtim }\end{array}$ & $\begin{array}{c}\text { From } \\
\text { Turkey }\end{array}$ & $\begin{array}{c}\text { From } \\
\text { FDA }\end{array}$ & $\begin{array}{c}\text { From } \\
\text { EMA }\end{array}$ \\
\hline 451 & 422 & 129 & 1 & 40 \\
\hline
\end{tabular}

Table 5: Medicines 2018.

\begin{tabular}{|c|c|c|c|c|}
\hline MA & Renewal & From Turkey & From FDA & From EMA \\
\hline 326 & 419 & 126 & 0 & 57 \\
\hline
\end{tabular}

Also approaching the Albanian legislation with the EU legislation will absolutely increase the number of drugs coming from these countries and will decrease the number of drugs coming from Ballkan region and Turkey, which $i$ think is very important because it will bring to the Albanian community qualitative, efficient and safety drugs.

\section{Recommendations}

Approaching the Albanian legislation with EU legislation regarding generic and also innovative medicines which can promote competition between different medicines for the same pathology reducing costs of therapy. This will bring a large number of originators and also generics drugs from the EU countries, USA, Japan.

\section{References}

1. National Agency for Medicines and Medical devices (2015) On drugs and pharmaceutical service. Law No. 105/2014, 31.07.2014. Tirana, Albania.

2. National Agency for Medicines and Medical devices (2015) Decision of the Council of Ministers No. 299, 08.04.2015. Tirana, Albania.

3. National register of medicines. 